\title{
Caffeic acid phenethyl ester ameliorates pulmonary inflammation and apoptosis reducing Nf- $\kappa \beta$ activation in blunt pulmonary contusion model
}

\author{
글 İsan Karaboğa, Ph.D.
}

Department of Emergency and Disaster Management, Tekirdağ Namık Kemal University School of Health, Tekirdağ-Turkey

\begin{abstract}
BACKGROUND: Pulmonary contusion (PC) is an important life-threatening clinical condition characterized by lung injury and inflammation. Caffeic acid phenethyl ester (CAPE) is a biological agent with potent antioxidant and anti-inflammatory effects. This study aimed to investigate the potential effects of CAPE on tissue damage, nuclear factor kappa-beta (Nf-k $\beta$ ) activity, inducible nitric oxide synthase (iNOS) synthesis, and pulmonary apoptosis in an experimental PC model.

METHODS: Forty adult Wistar albino rats were used in this study and divided into four groups as follows: control, PC, PC + CAPE, and CAPE. CAPE was administered intraperitoneally for seven days following PC formation ( $10 \mu \mathrm{mol} / \mathrm{kg}$, dissolved in dimethyl sulfoxide). Wet/dry weight ratio in lung tissue was determined. The pulmonary tissue was examined using hematoxylin-eosin and Masson's trichrome histochemical staining and also by scanning electron microscopy. Nf- $\kappa \beta$ and iNOS activities in the lungs were determined by the indirect immunohistochemical method. Pulmonary apoptosis was detected by the TUNEL method.
\end{abstract}

RESULTS: Increased leukocyte infiltration score, pulmonary edema, alveolar damage, and increased Nf- $\kappa \beta$ and iNOS activities were determined in the PC group. CAPE administration inhibited Nf- $\kappa \beta$ and iNOS activities and pulmonary apoptosis.

CONCLUSION: In this study, the findings showed that CAPE inhibited tissue damage by suppressing inflammatory mediators of Nf$\kappa \beta$ and iNOS activities. Also, CAPE was found to be protective in the lung tissue and could be used as a therapeutic agent.

Keywords: Apoptosis; inflammation; iNOS, Nf-к $\beta$; pulmonary contusion.

\section{INTRODUCTION}

Pulmonary contusion (PC) is the most important intrathoracic injury of blunt chest injuries that arises from falls or traffic accidents in children and adults. ${ }^{[1,2]} \mathrm{PC}$ is also the most important injury that triggers the local and systemic inflammatory response in multiple traumas. ${ }^{[3]}$ Cytokines and other pro-inflammatory mediators released from macrophages and leukocytes, which are active after blunt chest trauma, cause inflammation of lung tissue. ${ }^{[4]}$ Pulmonary edema, alveolarcapillary permeability, surfactant dysfunction, and ventilationperfusion mismatch are known to be the consequences of PC. ${ }^{[5,6]}$ No specific treatment option is available for patients with blunt chest trauma, which is a concern in emergency medicine and trauma care and symptomatic treatment is generally administered. ${ }^{[4]}$

Nuclear factor kappa-beta $(\mathrm{Nf}-\kappa \beta)$ is a transcription factor that has a central role in many biological processes, such as inflammation, apoptosis, and infections. ${ }^{[7,8]}$ Activation of $\mathrm{Nf}-\kappa \beta$ induces inflammation by triggering the transcription of pro-inflammatory genes. ${ }^{[9]}$ Recent studies reported that exposure to chest trauma caused $\mathrm{Nf}-\kappa \beta$ activation and increased the synthesis of pro-inflammatory cytokines, such as inducible nitric oxide synthase (iNOS) and interleukin-I beta $(I L-I \beta) \cdot{ }^{[10, I]}$ Chest trauma resulting in macrophage activation and increased pro-inflammatory cytokine synthesis induced apoptosis in pulmonary alveolar epithelial cells. ${ }^{[3,5]}$

Cite this article as: Karaboğa İ. Caffeic Acid Phenethyl Ester Ameliorates Pulmonary Inflammation and Apoptosis Reducing Nf- $\kappa \beta$ Activation in Blunt Pulmonary Contusion Model. Ulus Travma Acil Cerrahi Derg 2019;25:433-439.

Address for correspondence: İhsan Karaboğa, M.D.

Namık Kemal Üniversitesi Sağlık Yüksekokulu, Acil Yardım ve Afet Yönetimi Bölümü, 59030 Tekirdağ, Turkey

Tel: +90 282 - 2503119 E-mail: ihsankaraboga@gmail.com 
Caffeic acid phenethyl ester (CAPE), one of the most important biological components of propolis produced by worker bees, has strong anti-inflammatory and antiapoptotic effects. $\left[{ }^{[2,13]}\right.$ Koksel et al. ${ }^{[14]}$ (2006) demonstrated that CAPE suppressed antioxidative stress in the lung tissue and reduced inflammation in the lipopolysaccharide (LPS)-induced lung injury model in rats. The present study aimed to reveal the potential effects of CAPE on inflammation and apoptotic processes using light and scanning electron microscopic methods in the rat chest trauma model.

\section{MATERIALS AND METHODS}

\section{Experimental Design}

This study was performed at Tekirdag Namık Kemal University Application and Research Centre for Experimental Animals after obtaining permission from the local ethics committee (Permission number: 17/10/2017-7). Forty adult male (8-week-old) Wistar albino rats were divided into four groups as follows: control $(n=10), P C(n=10), P C+$ CAPE $(n=10)$, and CAPE. Chest trauma was created with the model previously described by Raghavendran et al. ${ }^{[15]}$ (2005). CAPE treatment was applied to the chest trauma model and chest trauma + CAPE groups for seven days dissolved in dimethyl sulfoxide ( $10 \mu \mathrm{mol} / \mathrm{kg}$, intraperitoneally). During the experimental period, the animals were kept under standard laboratory conditions $\left(22 \pm 2^{\circ} \mathrm{C} ; 60 \%\right.$ humidity; 12/12 dark-light cycles) and fed ad libitum with the standard diet. At the end of the seventh day, the rats were anesthetized (ketamine-xylazine; $90-10 \mathrm{mg} / \mathrm{kg}$ ) and sacrificed by drawing blood from the heart-opening through the midline. The left lung lobe was evaluated for edema and the right lung lobe for light and electron microscopic analysis.

\section{Wet/Dry Weight Ratio}

The fresh left superior lobe from each rat was weighed quickly after sacrificing for the evaluation of pulmonary edema. Wet/ Dry (W/D) weight ratio was calculated by reweighing samples held for $24 \mathrm{~h}$ at $80^{\circ} \mathrm{C}$ according to a previous study. ${ }^{[6]}$

\section{Histopathological Analysis}

Lung tissue specimens were fixed in 10\% neutral formalin. After fixation, paraffin blocks were prepared using routine histological methods. Five-micrometer-thick sections were stained with hematoxylin-eosin (H\&E) and Masson's trichrome stains. Histopathological changes, such as alveolar edema, vascular congestion, hemorrhage, and leukocyte infiltrations, were assessed in lung tissue. Extravascular leukocyte counts were determined and scored in H\&E-stained sections (0, no extravascular leukocytes; I, < 10 leukocytes; 2, 10-45 leukocytes; 3, >45 leukocytes) to determine the severity of inflammation. ${ }^{[17]}$ The distribution of connective tissue and the thickening of the alveolar wall were confirmed by Masson's trichrome staining in lung tissue. All histological examinations were performed using Olympus CX4I (Olympus, Japan) light microscope and image analysis system (Kameram Gen 2.I Image Analysis Software, Istanbul, Turkey).

\section{Immunohistochemical Staining}

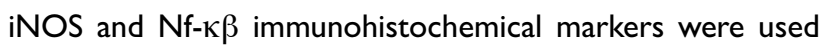
for the indirect immunohistochemical method. Primer anti-

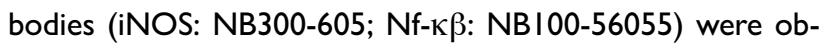
tained from Novus Biologicals (Littleton, CO, USA). Biotinylated secondary antibody and streptavidin peroxidase (Ultra Vision Detection System-HRP kit, Thermo Scientific/Lab Vision, Fremont, CA, USA) were used according to the manufacturer's instructions. Further, 3-amino-9-ethylcarbazole was used for iNOS staining, and 3,3'-diaminobenzidine chromogen was used for $\mathrm{Nf}-\kappa \beta$ staining to create contrast. Contrasting stains were made with Mayer's hematoxylin. iNOS and $\mathrm{Nf}-\kappa \beta$ positive stained cell numbers were expressed as positive stained cells $/ \mathrm{mm}^{2}$ for each group in lung tissue.

\section{Apoptosis}

Apoptotic cells in the lung tissue were detected by the terminal deoxynucleotidyl transferase dUTP nick-end labeling (TUNEL) method (S7I0I ApopTag Plus Peroxidase In Situ, Merck Millipore, Darmstadt, Germany). Apoptotic cells identified using intense brown nuclear staining were calculated as positive cells $/ \mathrm{mm} 2$ for each group.

\section{Scanning Electron Microscopy Analysis}

The specimens fixed in 2\% 4-(2-hydroxyethyl)-I-piperazineethanesulfonic acid (HEPES) buffered glutaraldehyde solution overnight at $4^{\circ} \mathrm{C}$ were used for ultrastructural analysis of lung tissue. After fixation, the tissues were rinsed with 0.I M HEPES and dehydrated with ethanol. They were dried using hexamethyldisilazane. The specimens were examined using scanning electron microscopy (SEM) (Quanta Feg 250, FEI, USA) at Tekirdag Namık Kemal University Scientific and Technological Research and Application Center.

\section{Statistical Analysis}

Data were evaluated using the PASW Statistics 18.0.0 (SPSS Inc, IL, USA) statistical program. The numerical parameters of the groups were evaluated using a nonparametric test (Kruskal-Wallis), and the significance of the values obtained in the two-way comparison was measured using the MannWhitney $U$ test. P-values $<0.05$ were considered statistically significant.

\section{RESULTS}

\section{Effects of CAPE On Pulmonary Architecture}

Histopathological changes in the lungs were assessed using $\mathrm{H} \& \mathrm{E}$ and Masson's trichrome staining under a light microscope. Figure I shows the general tissue structure and infiltration score in H\&E-stained lung sections. The control group exhibited a normal histological structure (Fig. Ia). Intense in- 

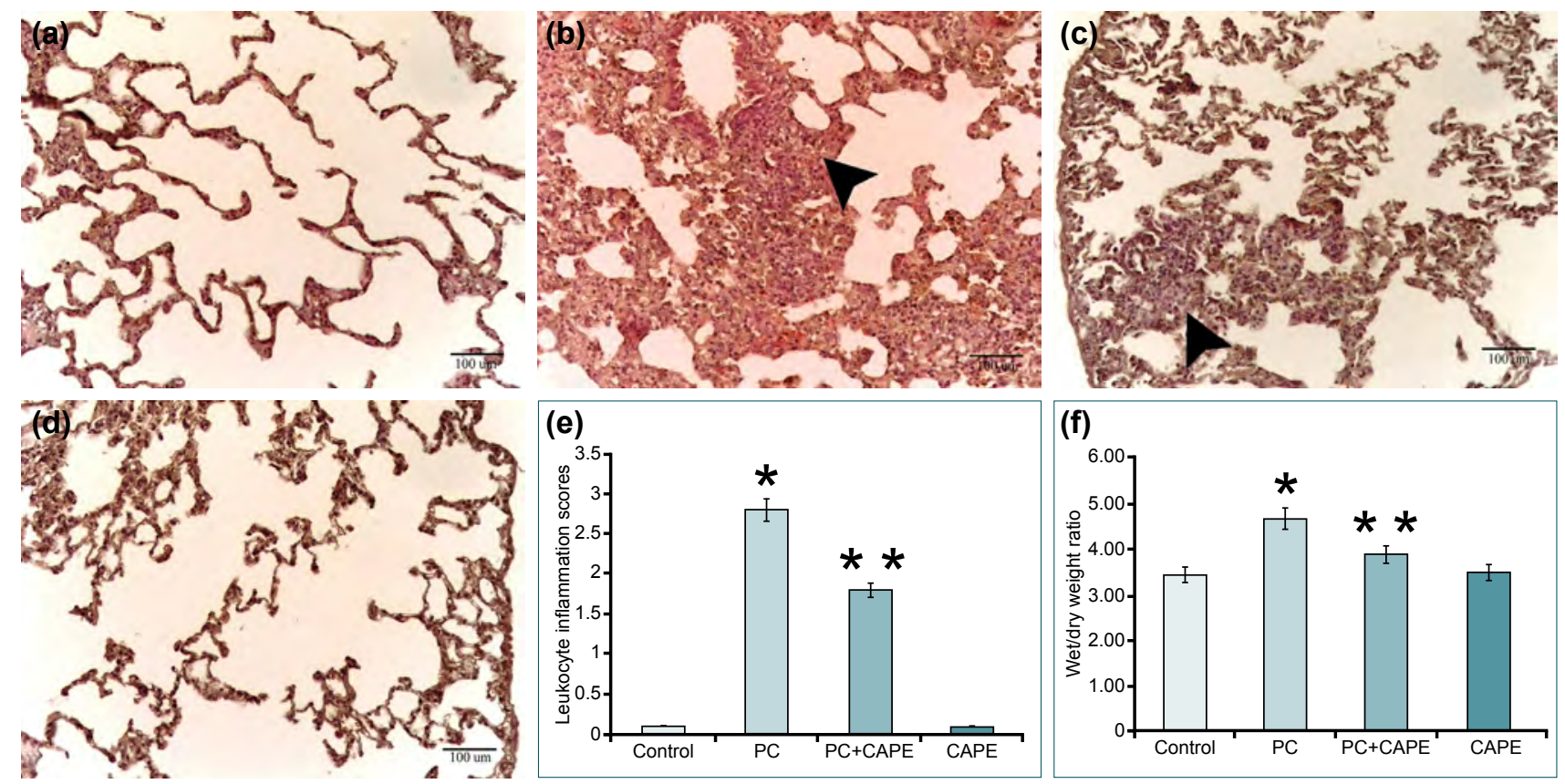

Figure 1. Effects of CAPE on pulmonary tissue. (a) Control, normal histological architecture. (b) PC, peribronchial and alveolar inflammation. (c) PC + CAPE, decreased inflammation in lung tissue. (d) CAPE, no histopathological change. (e) Lung leukocyte inflammation scores. (f) Effects of CAPE on W/D weight ratios (arrowhead; leukocyte infiltration, scale bar; $100 \mu \mathrm{m}, \mathrm{H} \& \mathrm{E}$, ${ }^{*} \mathrm{p}<0.001 \mathrm{compared}$ with the control group; ${ }^{* *} p<0.001$ compared with the $\mathrm{PC}$ group).

flammatory cell infiltration was seen in the PC group (Fig. Ib). Inflammatory cell infiltration in the PC + CAPE group was attenuated compared with that in the chest trauma group (Fig. Ic). The CAPE group showed normal histological architectures similar to that in the control group (Fig. Id). As shown in Figure le, CAPE treatment caused a significant reduction in the leukocyte infiltration score.
The W/D weight ratios determined as pulmonary edema size are shown in Figure If. The PC group showed increased $W / D$ ratio compared with the control group $(p<0.00 I)$. The CAPE-administered group exhibited significantly decreased $W / D$ ratio compared with the $P C$ group $(p<0.00 I)$. No significant difference in W/D ratio was observed between the control and CAPE groups.

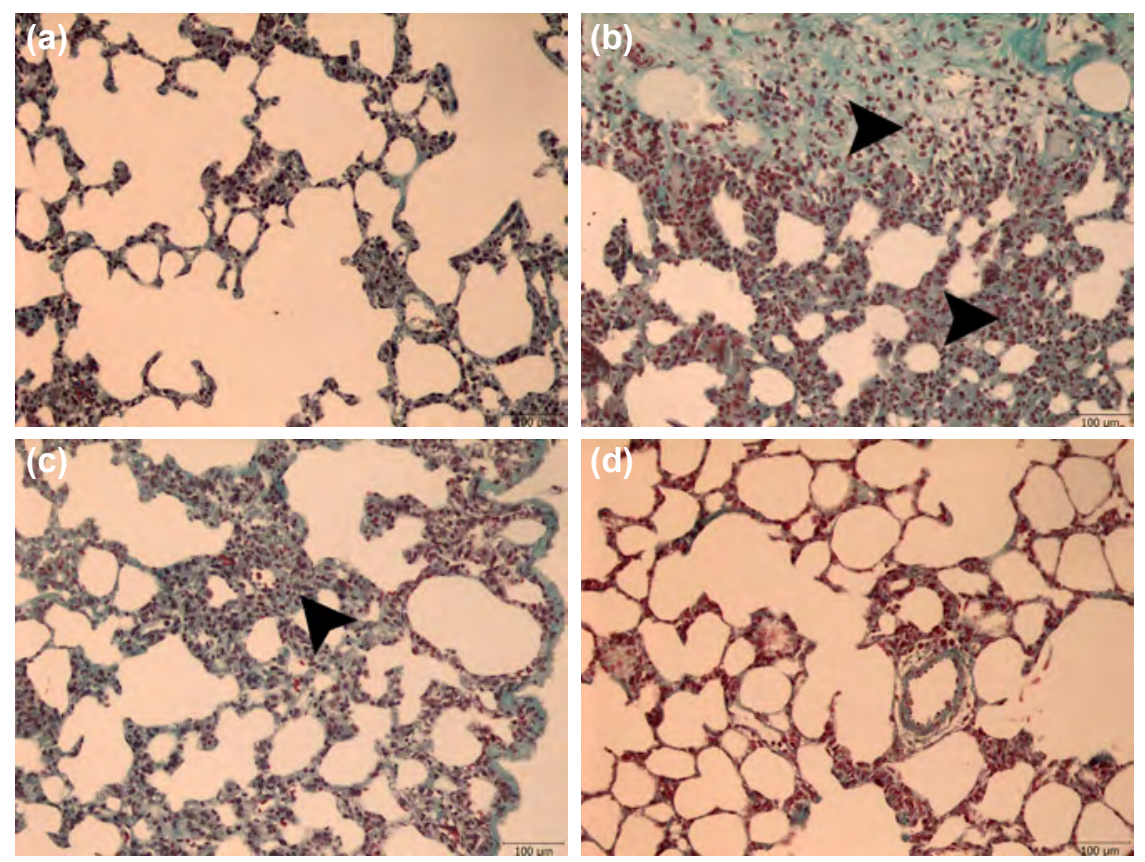

Figure 2. Masson's trichrome-stained pulmonary tissue. (a) Control. (b) PC, increased edema and alveolar infiltration. (c) PC + CAPE, decreased infiltration. (d) CAPE group similar to the control group (Masson's trichrome, scale bar; $100 \mu \mathrm{m}$ ). 

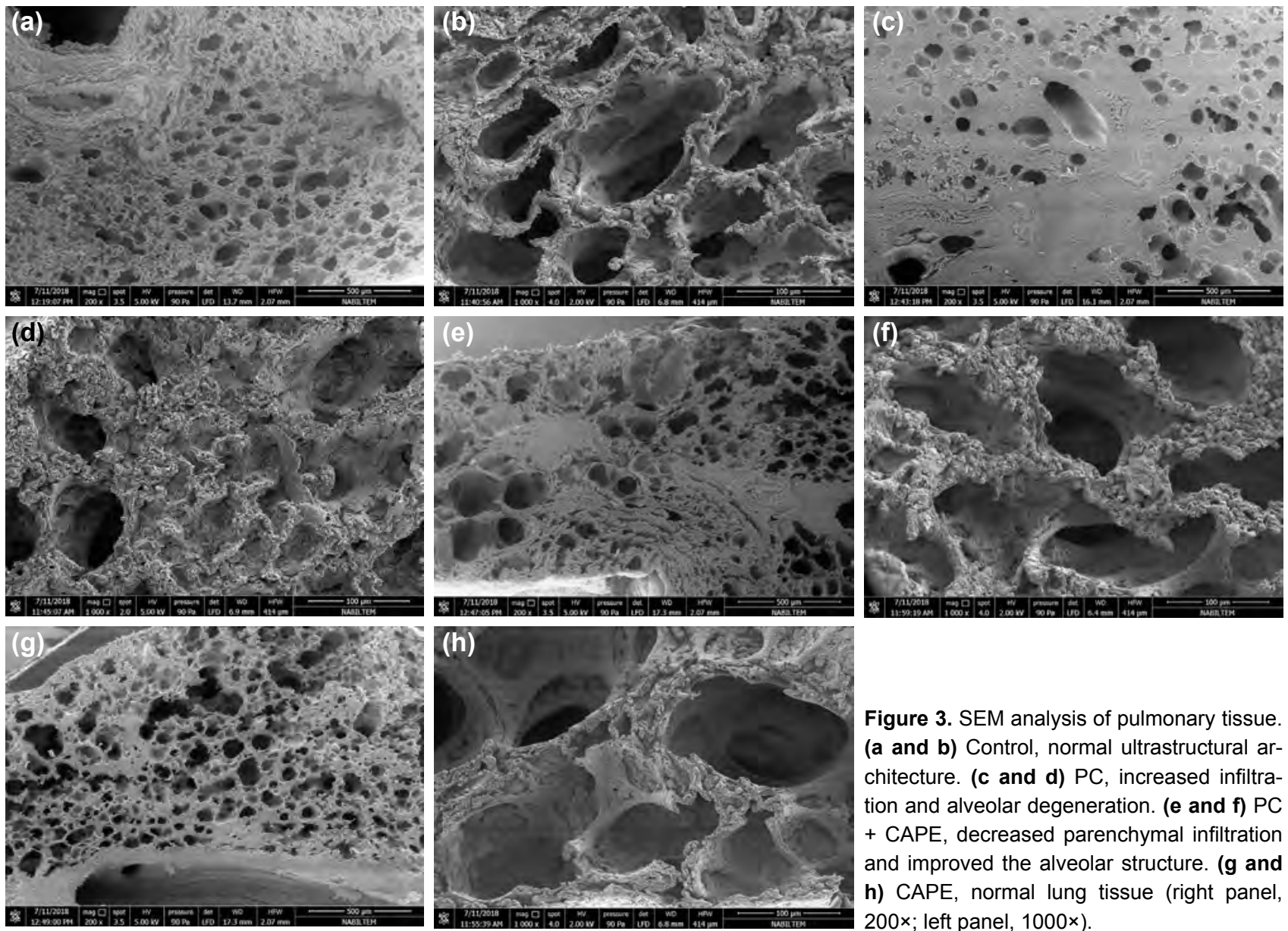

Figure 3. SEM analysis of pulmonary tissue. (a and b) Control, normal ultrastructural architecture. (c and d) PC, increased infiltration and alveolar degeneration. (e and f) PC + CAPE, decreased parenchymal infiltration and improved the alveolar structure. ( $g$ and h) CAPE, normal lung tissue (right panel, 200x; left panel, 1000x).

The findings of Masson's trichrome staining revealed that the chest trauma caused thickened alveolar wall and edema or increased connective tissue in areas of inflammation on comparing the control and PC groups (Fig. $2 a$ and $2 b$ ). In addition,
Masson's trichrome staining showed evidence of decreased inflammation in the CAPE-treated group (Fig. 2c).

SEM findings of lung tissue examined at different magnifica-
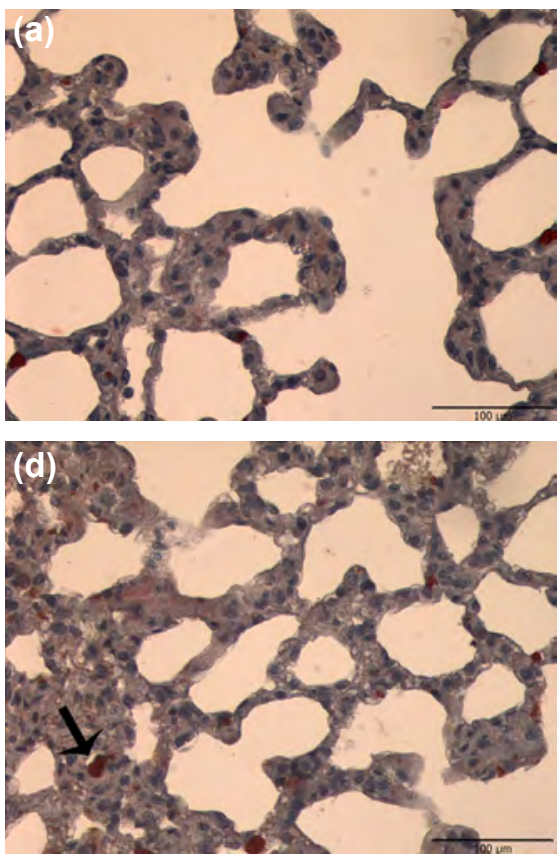
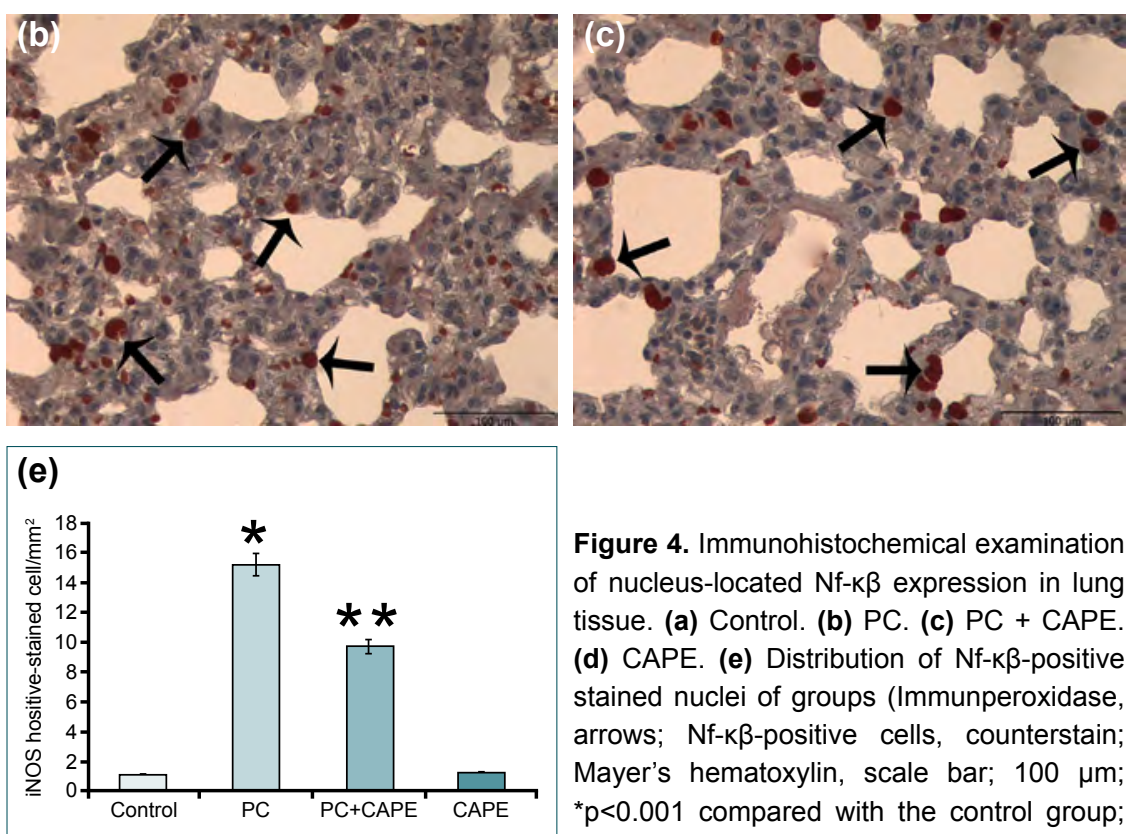

Figure 4. Immunohistochemical examination of nucleus-located Nf-k $\beta$ expression in lung tissue. (a) Control. (b) PC. (c) PC + CAPE. (d) CAPE. (e) Distribution of Nf-K $\beta$-positive stained nuclei of groups (Immunperoxidase, arrows; Nf-kß-positive cells, counterstain; Mayer's hematoxylin, scale bar; $100 \mu \mathrm{m}$; ${ }^{*} p<0.001$ compared with the control group; ${ }^{* *} p<0.001$ compared with the PC group). 

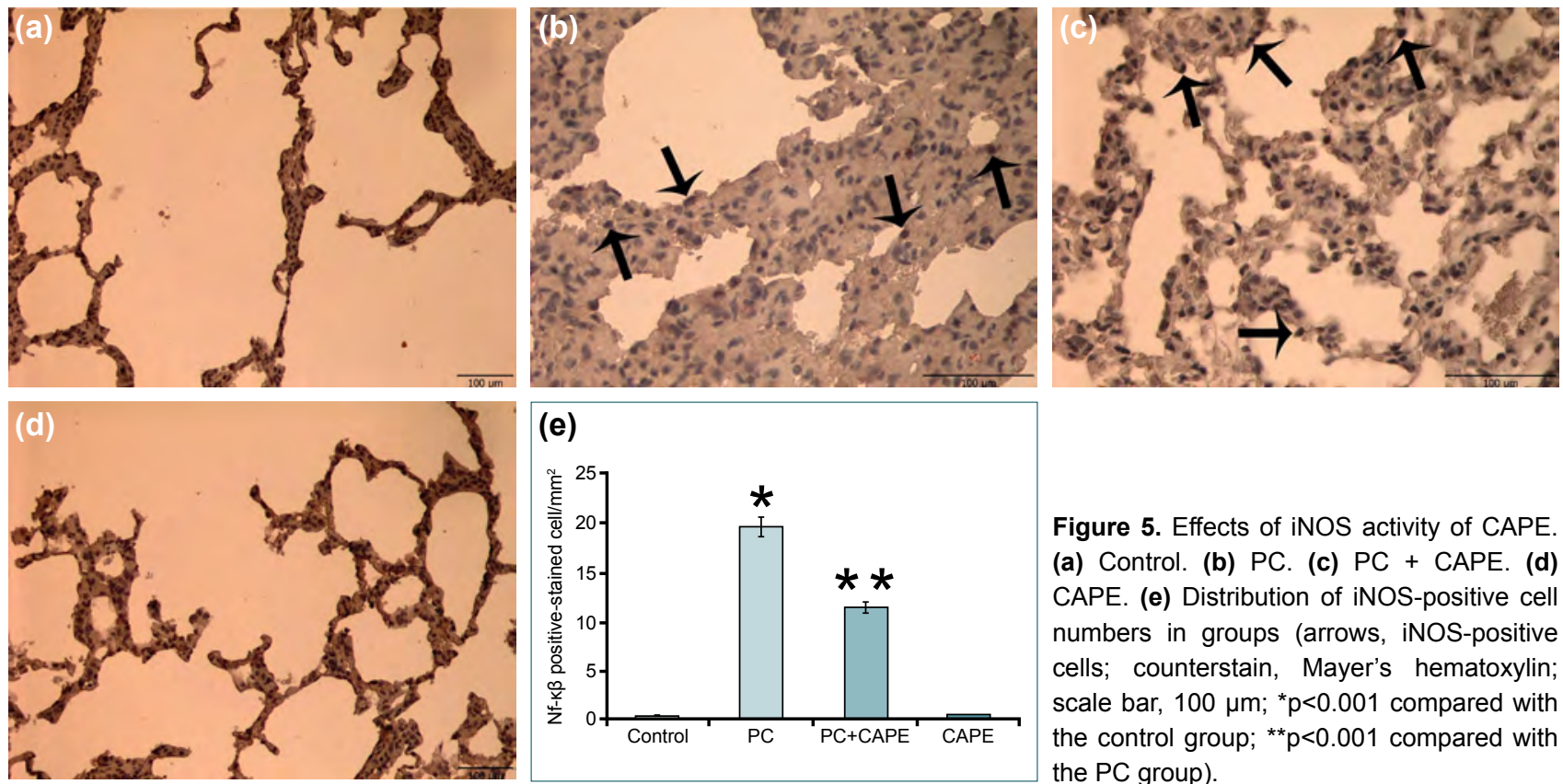

Figure 5. Effects of iNOS activity of CAPE. (a) Control. (b) PC. (c) PC + CAPE. (d) CAPE. (e) Distribution of iNOS-positive cell numbers in groups (arrows, iNOS-positive cells; counterstain, Mayer's hematoxylin; scale bar, $100 \mu \mathrm{m} ;{ }^{*} p<0.001$ compared with the control group; ${ }^{* *} p<0.001$ compared with the PC group).

tions are presented in Figure 3. SEM analysis results were consistent with the findings of H\&E and Masson's trichrome staining. Increased edema, infiltration, and alveolar disruption were found in the chest trauma group (Fig. 3c-d). Decreased pathological degeneration was detected in the PC + CAPE group, and the observations were consistent with the findings of the light microscopic examination (Fig. 3e-f).

\section{Effects of CAPE on iNOS and Nf-k $\beta$ Immunoreactivity}

The immunohistochemical expression of iNOS is shown in Figure 4. The control group showed rare iNOS immunoreactivity in some alveolar epithelial cells (Fig. 4a). iNOS ex- pression increased, especially in the areas of inflammation, in the PC group (Fig. 4b). Decreased expression was detected in the PC + CAPE group compared with the PC group (Fig. 4c). The CAPE group was similar to the iNOS expression control group (Fig. 4d). iNOS-positive staining cell counts of the groups are presented in Figure 4e.

The Nf- $\kappa \beta$ immunohistochemical expression was observed as nuclear brown staining. A statistically significant decrease in the number of positively stained cells was noted in the group treated with CAPE despite the increase in the $\mathrm{Nf}-\kappa \beta$ immunohistochemical expression in the PC group $(p<0.001$, Fig. $5 \mathrm{~b}$ and $\mathrm{c}$ ). The control and CAPE groups were similar in
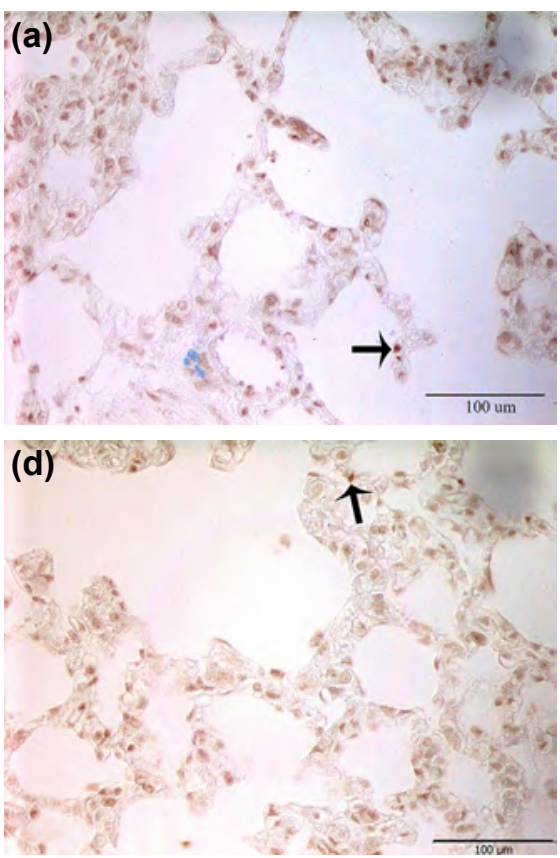

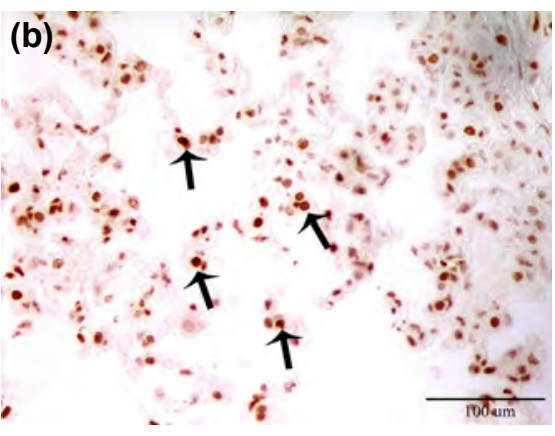

(e)

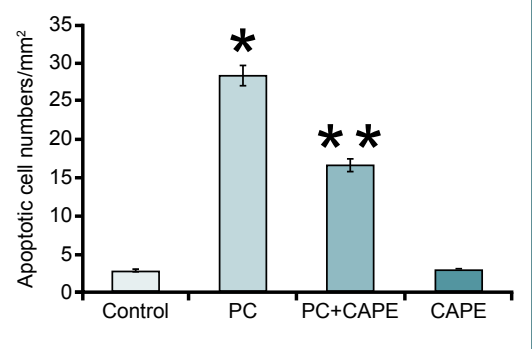

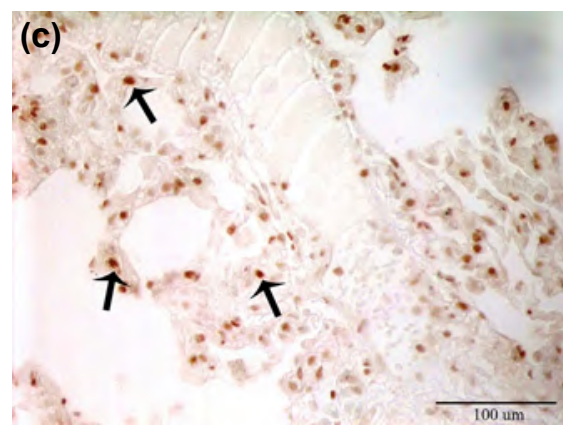

Figure 6. Apoptotic cells in lung tissue. (a) Control, a few apoptotic cells. (b) PC, increased number of apoptotic cells in contused lung tissue. (c) Decreased number of apoptotic cells. (d) Rare apoptotic cells in lung tissue. (e) Distribution of apoptotic cells in groups (scale bar, $100 \mu \mathrm{m}$; arrows, TUNEL-positive stained apoptotic cells; ${ }^{*} p<0.001$ compared with the control group; ${ }^{* *} p<0.001$ compared with the PC group). 
terms of $\mathrm{Nf}-\kappa \beta$ immunohistochemical expression (Fig. $5 \mathrm{a}-\mathrm{e}$ ).

\section{Effects of CAPE On Pulmonary Apoptosis}

The number of apoptotic cells in the lung tissue was determined by the TUNEL method, which marked the broken DNA ends. The findings are presented in Figure 6. An increased TUNEL-positive cell number was detected in the PC group compared with the control group $(p<0.001$, Fig. $6 b$ and $c)$. The apoptotic cell number showed a significant decline in the CAPE-treated group compared with the PC group (Fig. 6e). These results clearly demonstrated the potential antiapoptotic effects of CAPE in the lung tissue after chest trauma.

\section{DISCUSSION}

PC is an important clinical problem accompanied by multiple traumas or chest trauma. PC affects the patients' prognosis in emergency medicine. ${ }^{[18]}$ One of the most important pathophysiological factors in PC that arises from blunt chest trauma is the progressive inflammatory response. ${ }^{[1,19]}$ An excessive inflammatory response leads to increased alveolar-capillary permeability, leukocyte infiltration, edema, and respiratory distress. ${ }^{[20,21]}$ Moreover, PC is associated with the increased pro-inflammatory cytokine release and alveolar cell apoptosis. ${ }^{[3,22]}$ Thus, effective treatment is the most important issue in managing patients with PC and preventing complications. This study used different methods in the experimental PC model to demonstrate that CAPE supported tissue healing by suppressing inflammation in the lung tissue.

Histopathological changes, such as infiltration, edema, and alveolar deterioration, in the pulmonary tissues of experimental PC models, have been revealed in many studies. ${ }^{[23,24]}$ Sirmalı et al. ${ }^{[25]}(2013)$ showed that CAPE inhibited tissue damage by its antioxidative action in the rat PC model. Consistent with the findings of the aforementioned study, CAPE improved lung tissue damage in the present study. In addition, histopathological changes in the lung tissue were also demonstrated in this study using the Masson's trichrome stain. Moreover, SEM analysis results supported the findings.

This novel study showed that CAPE inhibited apoptosis by reducing the pulmonary levels of pro-inflammatory mediators iNOS and Nf- $\kappa \beta$ in the PC model.

The Nf- $\kappa \beta /$ Rel transcriptional family has a vital role in the inflammatory process because of the ability of pro-inflammatory genes to induce transcription. ${ }^{[26]}$ Nuclear translocation of cytoplasmic complexes of $\mathrm{Nf}-\kappa \beta$ leads to the induction of pro-inflammatory cytokines, chemokines, adhesion molecules, and $\mathrm{iNOS} .{ }^{\left[{ }^{10]} \mathrm{Nf}-\kappa \beta\right.} \beta$ has been reported to be overexpressed in many inflammatory diseases, such as inflammatory bowel diseases, asthma, multiple sclerosis, and rheumatoid arthritis. ${ }^{[7,26]}$

Experimental studies demonstrated the role of $\mathrm{Nf}-\mathrm{\kappa} \beta$ activation in pulmonary damage that arises from chest trauma.
Relja et al. ${ }^{[22]}(2018)$ reported that increased $\mathrm{Nf}-\kappa \beta$ activation in the blunt chest trauma model was associated with local tumor necrosis factor-alpha (TNF- $\alpha$ ) and leukocyte infiltration. Similarly, Wu et al. ${ }^{[27]}(20 / 3)$ showed that $\mathrm{Nf}-\kappa \beta$ increased in proportion to the level of systemic TNF- $\alpha$ and IL-I $\beta$ in an experimental pulmonary contusion model. In the present study, increased $\mathrm{Nf}-\kappa \beta$ activation consistent with histopathological changes was demonstrated immunohistochemically.

Nitric oxide (NO) is involved in biological functions, including inflammation in the lung. iNOS activity causes an increase in $\mathrm{NO}$ production in the lung. ${ }^{[28]} \mathrm{NO}$ combines rapidly with oxygen radical superoxide in the lungs, leading to the formation of highly toxic and reactive nitrogen species, such as peroxynitrite. [17] In PC models, damage to lung tissue is associated with NO, and iNOS activity inhibits tissue destruction and apoptosis. [29,30] The present study also showed that CAPE administration improved the tissue structure with decreasing iNOS activity and significantly reduced the number of apoptotic cells in the lungs. CAPE has been reported to suppress NO production and iNOS activity in different in vivo and in vitro models. ${ }^{[1-33]}$

\section{Conclusions}

In addition to the data obtained from a previous study reporting that CAPE inhibited oxidative stress and inhibited tissue damage, ${ }^{[25]}$ this study used light and electron microscopic methods to demonstrate that CAPE reduced tissue damage by suppressing $\mathrm{Nf}-\mathrm{\kappa} \beta$ and iNOS activity in the lung tissue. Therefore, CAPE can be used as a powerful anti-inflammatory agent to prevent tissue damage resulting from chest trauma and to suppress inflammation.

\section{Acknowledgment}

This study was supported by Tekirdag Namık Kemal University, Scientific Research Projects Commission (NKUBAP.23. GA.18.160).

\section{Conflict of interest: None declared.}

\section{REFERENCES}

1. Ismail MF, al-Refaie RI. Chest trauma in children, single center experience. [Article in English, Spanish]. Arch Bronconeumol 2012;48:362-6.

2. Inan M, Ayvaz S, Sut N, Aksu B, Basaran UN, Ceylan T. Blunt chest trauma in childhood. ANZ J Surg 2007;77:682-5. [CrossRef]

3. Seitz DH, Perl M, Mangold S, Neddermann A, Braumüller ST, Zhou S, et al. Pulmonary contusion induces alveolar type 2 epithelial cell apoptosis: role of alveolar macrophages and neutrophils. Shock 2008;30:537-44.

4. Türüt H, Ciralik H, Kilinc M, Ozbag D, Imrek SS. Effects of early administration of dexamethasone, $\mathrm{N}$-acetylcysteine and aprotinin on inflammatory and oxidant-antioxidant status after lung contusion in rats. Injury 2009;40:521-7. [CrossRef]

5. Topcu-Tarladacalisir Y, Tarladacalisir T, Sapmaz-Metin M, Karamustafaoglu A, Uz YH, Akpolat M, et al. N-Acetylcysteine counteracts oxidative stress and protects alveolar epithelial cells from lung contusion-induced apoptosis in rats with blunt chest trauma. J Mol Histol 2014;45:463-71. [CrossRef]

6. Cohn SM. Pulmonary contusion: review of the clinical entity. J Trauma 
1997;42:973-9. [CrossRef]

7. Taniguchi $\mathrm{K}$, Karin M. NF- $\mathrm{KB}$, inflammation, immunity and cancer: coming of age. Nat Rev Immunol 2018;18:309-24. [CrossRef]

8. Matteucci C, Minutolo A, Marino-Merlo F, Grelli S, Frezza C, Mastino A, et al. Characterization of the enhanced apoptotic response to azidothymidine by pharmacological inhibition of NF-kB. Life Sci 2015;127:90-7.

9. Gross CM, Kellner M, Wang T, Lu Q, Sun X, Zemskov EA, et al. LPSinduced Acute Lung Injury Involves NF-KB-mediated Downregulation of SOX18. Am J Respir Cell Mol Biol 2018;58:614-24. [CrossRef]

10. Ehrnthaller C, Flierl M, Perl M, Denk S, Unnewehr H, Ward PA, et al. The molecular fingerprint of lung inflammation after blunt chest trauma. Eur J Med Res 2015;20:70. [CrossRef]

11. Ayvaz S, Aksu B, Karaca T, Cemek M, Tarladacalisir YT, Ayaz A, et al. Effects of methylene blue in acute lung injury induced by blunt chest trauma. Hippokratia 2014;18:50-6.

12. Akyol S, Ugurcu V, Altuntas A, Hasgul R, Cakmak O, Akyol O. Caffeic acid phenethyl ester as a protective agent against nephrotoxicity and/or oxidative kidney damage: a detailed systematic review. ScientificWorldJournal 2014;2014:561971. [CrossRef]

13. Kus I, Colakoglu N, Pekmez H, Seckin D, Ogeturk M, Sarsilmaz M. Protective effects of caffeic acid phenethyl ester (CAPE) on carbon tetrachloride-induced hepatotoxicity in rats. Acta Histochem 2004;106:289-97.

14. Koksel O, Ozdulger A, Tamer L, Cinel L, Ercil M, Degirmenci U, et al. Effects of caffeic acid phenethyl ester on lipopolysaccharide-induced lung injury in rats. Pulm Pharmacol Ther 2006;19:90-5. [CrossRef]

15. Raghavendran K, Davidson BA, Woytash JA, Helinski JD, Marschke CJ, Manderscheid PA, et al. The evolution of isolated bilateral lung contusion from blunt chest trauma in rats: cellular and cytokine responses. Shock 2005;24:132-8. [CrossRef]

16. Kao MC, Yang CH, Sheu JR, Huang CJ. Cepharanthine mitigates proinflammatory cytokine response in lung injuryinduced by hemorrhagic shock/resuscitation in rats. Cytokine 2015;76:442-8. [CrossRef]

17. Basaran UN, Ayvaz S, Aksu B, Karaca T, Cemek M, Karaboga I, et al. Desferrioxamine reduces oxidative stress in the lung contusion. ScientificWorldJournal 2013;2013:376959. [CrossRef]

18. Boybeyi O, Bakar B, Aslan MK, Atasoy P, Kisa U, Soyer T. Evaluation of dimethyl sulfoxide and dexamethasone on pulmonary contusion in experimental blunt thoracic trauma. Thorac Cardiovasc Surg 2014;62:710-5.

19. Rocksén D, Gryth D, Druid H, Gustavsson J, Arborelius UP. Pathophysiological effects and changes in potassium, ionised calcium, glucose and haemoglobin early after severe blunt chest trauma. Injury 2012;43:632-7.

20. Aksu B, Ayvaz S, Aksu F, Karaca T, Cemek M, Ayaz A, et al. Effects of sphingosylphosphorylcholine against oxidative stress and acute lung injury induced by pulmonary contusion in rats. J Pediatr Surg 2015;50:591-7. [CrossRef]

21. Wang ND, Stevens MH, Doty DB, Hammond EH. Blunt chest trauma: an experimental model for heart and lung contusion. J Trauma 2003;54:744-8. [CrossRef]

22. Relja B, Wagner N, Franz N, Dieteren S, Mörs K, Schmidt J, et al. Ethyl pyruvate reduces acute lung damage following trauma and hemorrhagicshock via inhibition of NF- $\mathrm{KB}$ and HMGB1. Immunobiology 2018;223:310-8. [CrossRef]

23. Wu XJ, Xia ZY, Wang LL, Luo T, Zhan LY, Meng QT, et al. Effects of penehyclidine hydrochloride on pulmonary contusion from blunt chest trauma in rats. Injury 2012;43:232-6. [CrossRef]

24. Torun AC, Tutuncu S, Ustun B, Akdemir HU. A Study of the Therapeutic Effects of Resveratrol on Blunt Chest Trauma-Induced Acute Lung Injury in Rats and the Potential Role of Endocan as a Biomarker of Inflammation. Inflammation 2017;40:1803-10. [CrossRef]

25. Sirmalı M, Solak O, Tezel C, Sırmalı R, Ginis Z, Atik D, et al. Comparative analysis of the protective effects of caffeic acid phenethyl ester (CAPE) on pulmonary contusion lung oxidative stress and serum copper and zinc levels in experimental rat model. Biol Trace Elem Res 2013;151:50-8.

26. Tak PP, Firestein GS. NF-kappaB: a key role in inflammatory diseases. J Clin Invest 2001;107:7-11. [CrossRef]

27. Wu X, Song X, Li N, Zhan L, Meng Q, Xia Z. Protective effects of dexmedetomidine on blunt chest trauma-induced pulmonary contusion in rats. J Trauma Acute Care Surg 2013;74:524-30. [CrossRef]

28. Ricciardolo FL, Sterk PJ, Gaston B, Folkerts G. Nitric oxide in health and disease of the respiratory system. Physiol Rev 2004;84:731-65. [CrossRef]

29. Dolkart O, Amar E, Shapira S, Marmor S, Steinberg EL, Weinbroum AA. Protective effects of rosuvastatin in a rat model of lung contusion: Stimulation of the cyclooxygenase 2-prostaglandin E-2 pathway. Surgery 2015;157:944-53. [CrossRef]

30. Kozan A, Kilic N, Alacam H, Guzel A, Guvenc T, Acikgoz M. The Effects of Dexamethasone and L-NAME on Acute Lung Injury in Rats with Lung Contusion. Inflammation 2016;39:1747-56. [CrossRef]

31. Kart A, Cigremis Y, Karaman M, Ozen H. Caffeic acid phenethyl ester (CAPE) ameliorates cisplatin-induced hepatotoxicity in rabbit. Exp Toxicol Pathol 2010;62:45-52. [CrossRef]

32. Barlas FB, Erdoğan S. Caffeic acid phenethyl ester protects lung alveolar epithelial cells from cigarette smoke-induced damage. Turk J Med Sci 2015;45:534-41. [CrossRef]

33. Shi Y, Guo L, Shi L, Yu J, Song M, Li Y. Caffeic Acid Phenethyl Ester inhibit Hepatic Fibrosis by Nitric Oxide Synthase and Cystathionine Gamma-Lyase in Rats. Med Sci Monit 2015;21:2774-80. [CrossRef]

\section{DENEYSEL ÇALIŞMA - ÖZET}

\section{Kafeik asit fenetil ester künt pulmoner kontüzyon modelinde pulmoner enflmasyon ve apoptozisi Nf- $\kappa \beta$ aktivasyonunu azaltarak iyileştirir \\ Dr. İhsan Karaboğa}

Tekirdağ Namık Kemal Üniversitesi Sağlık Yüksekokulu, Acil Yardım ve Afet Yönetimi Bölümü, Tekirdağ

AMAÇ: Pulmoner kontüzyon (PC), akciğer hasarı ve enflamasyon ile karakterize, hayatı tehdit eden önemli bir klinik durumdur. Kafeik asit fenetil ester (CAPE), güçlü antioksidan ve anti-enflamatuvar etkileri olan biyolojik bir ajandır. Bu çalışmada, CAPE'nin deneysel PC modelinde doku hasarı, nükleer faktör kappa-beta (Nf-к $\beta$ ) aktivitesi, indüklenebilir nitrik oksit sentaz (iNOS) sentezi ve pulmoner apoptozis üzerindeki etkileri araştırıldı. GEREÇ VE YÖNTEM: Çalışmada 40 yetişkin Wistar albino sıçanı kullanıııı ve dört gruba ayrıldı: Kontrol, PC, PC + CAPE ve CAPE. CAPE, PC oluşumunu takiben yedi gün boyunca intraperitonal olarak uygulandı (dimetil sülfoksit içinde çözülmüş $10 \mathrm{umol} / \mathrm{kg}$ ). Akciğer dokusunda ıslak/kuru ağırlık oranı belirlendi. Pulmoner doku hematoksilen-eosin ve masson trikrom histokimyasal boyaması ile ve taramalı elektron mikroskobu ile incelendi.

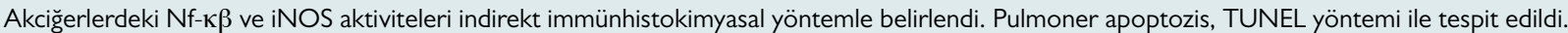
BULGULAR: Pulmoner kontüzyon grubunda artmış lökosit infiltrasyon skoru, pulmoner ödem, alveoler hasar ve artmış Nf- $\kappa \beta$ ve iNOS aktiviteleri tespit edildi. CAPE uygulaması Nf- $\kappa \beta$ ve iNOS aktivitelerini ve pulmoner apoptozu azaltmaktadır.

TARTIŞMA: Çalışmanın sonuçları, CAPE'nin Nf- $\kappa \beta$ ve iNOS enflamatuvar mediatörlerini baskılayarak doku hasarını engellediğini ettiğini açıkça göstermektedir. Ayrıca, CAPE'nin akciğer dokusunda koruyucu olduğunu ve terapötik bir ajan olarak kullanılabileceğini göstermektedir. Anahtar sözcükler: Apoptozis; enflamasyon; indüklenebilir nitrik oksit sentaz; nükleer faktör kappa-beta; pulmoner kontüzyon.

Ulus Travma Acil Cerrahi Derg 2019;25(5):433-439 doi: 10.5505/tjtes.2018.51694 